\title{
El enfrentamiento entre filósofos y tiranos, de la biografía helenística a la tardoantigua: evoluciones de un tópico biográfico*
}

\author{
Sergi Grau \\ Institut Català d'Arqueologia Clàssica - Universitat de Barcelona \\ s.grau@ub.edu \\ ORCID iD: https://orcid.org/0000-0001-6599-0752
}

\section{Confrontation between Philosophers and Tyrants from Hellenistic to Late Antique Biography: Evolutions of a Biographical Pattern}

El enfrentamiento entre filósofos y personajes poderosos es un elemento habitual en las biografías helenísticas. En ocasiones, este enfrentamiento es simplemente dialéctico, pero no faltan casos de auténticos «martirios» filosóficos paganos cruentos, con persecuciones en toda regla. Estas muertes otorgan al filósofo una heroización celestial, al menos según los epigramas integrados en la peripecia biográfica, seguramente por la asociación con el culto a los tiranicidas y, en general, a los héroes que reciben una muerte violenta en la tradición mitológica. Inspirado, plausiblemente, en la muerte de Sócrates, el tópico se perpetúa en las vidas
The confrontation between philosophers and powerful characters is a common element in Hellenistic biographies. Occasionally, this confrontation is simply dialectical, but there are no shortage of cases of genuine, bloody pagan philosophical «martyrdoms», with persecutions in every sense of the word. These deaths give the philosopher a celestial heroisation, at least according to the epigrams integrated into his biographical narration, probably because of the association with the cult of tyrannicides and, in general, heroes who receive a violent death in the mythological tradition. Inspired, plausibly, in the death of Socrates, the pattern is perpet-

* Este trabajo se integra en el proyecto «Mecanismos de representación del pasado y dinámicas de la performance en la Grecia antigua», dirigido por J. Carruesco y financiado por el Ministerio de Economía y competitividad (FFI2015-68548-P). Forma parte, asimismo, del grupo de investigación de la Generalitat de Catalunya «Logotekhnia. Estudis de cultura grega antiga», dirigido por X. Riu (2017 SGR 894). Una primera versión del mismo fue presentada en el II seminario internacional sobre el concepto de hombre divino y su recepción (30-31 de mayo de 2019, Madrid): agradezco a los organizadores su invitación y a los participantes sus aportaciones y comentarios durante el debate. Deseo agradecer también, finalmente, las interesantes sugerencias y comentarios de los dos evaluadores anónimos, que han contribuido notablemente a mejorar el resultado final.

Copyright: (C) 2020 CSIC. Este es un artículo de acceso abierto distribuido bajo los términos de la licencia de uso y distribución Creative Commons Reconocimiento 4.0 Internacional (CC BY 4.0). 
de los hombres divinos tardoantiguos, donde, sin embargo, no se produce en ningún caso la muerte heroica y divinizante del filósofo, a pesar de que hubiera sido un contrapunto excelente a las actas de martirios cristianos, cuya literatura empieza a florecer precisamente en este período. uated in the lives of the pagan holy men. However, these latter confrontations do not cause in any case the heroic and divinising death of the philosopher, although it would have been an excellent counterpoint to the acts of Christian martyrdoms, whose literature begins to flourish just in this period.
Palabras clave: Biografía de filósofos griegos; tópicos biográficos; tiranos; Antigüedad Tardía; Eunapio de Sardes; Diógenes Laercio.
Key words: Ancient Greek biography of philosophers; biographical patterns; tyrants; Late Antiquity; Eunapius of Sardes; Diogenes Laertius.

Cómo citar este artículo / Citation: Grau, Sergi 2020: «El enfrentamiento entre filósofos y tiranos, de la biografía helenística a la tardoantigua: evoluciones de un tópico biográfico», Emerita 88 (1), pp. 101-128.

Un ingrediente que no suele faltar en las biografías helenísticas de filósofos griegos antiguos es un episodio de enfrentamiento, dialéctico o incluso físico, con personajes que detentan el poder, especialmente tiranos, pero también monarcas o emperadores. Según Chitwood 2004, p. 10, este choque de personalidades significa oeste contra este, democracia contra tiranía, libertad contra esclavitud, educación contra ignorancia, civilización contra barbarie, simplicidad y ascetismo contra lujuria y poder. Chitwood, no obstante, centra únicamente sus análisis en los filósofos objeto de su estudio, es decir, Empédocles y Demócrito, de manera que, aunque sus conclusiones son sustancialmente ciertas, conviene, según creemos, extender el análisis a un mayor número de biografías de filósofos para obtener una panorámica más amplia y variada de las diferentes manifestaciones, variantes y evoluciones del tópico. De hecho, tal como veremos, desde el punto de vista de la construcción narrativa, el enfrentamiento contra el tirano suele caracterizar ineludiblemente al filósofo como un partidario insobornable de la democracia y a la vez como un asceta inquebrantable, que no cede a honores ni sobornos, ni siquiera a la vida regalada que la sumisión al tirano le facilitaría. Es por ello que estos filósofos reciben habitualmente una valoración altamente positiva en la tradición biográfica, mientras que, al contrario, los que hacen la corte a los tiranos son tratados poco menos que como depravados en sus costumbres.

En realidad, el modelo narrativo, como tantas otras veces, es el del mito: sin duda, la imagen de Creonte y Antígona, Edipo y Tiresias, o Heracles y los Heraclidas perseguidos por el tirano Euristeo funcionan como referentes claros para la construcción de los relatos biográficos que nos ocupan, y la 
imagen misma del tirano es un claro reflejo del carácter excesivo del héroe en la mitología griega ${ }^{1}$. Incluso el folclore está repleto de este tipo de narrativa: el monarca a quien un sabio hace entrar en razón, o el sabio que da respuestas agudas a las preguntas más o menos capciosas del rey, e incluso los duelos dialécticos de reyes y sabios, o el célebre motivo del hombre pobre que en el fondo es más feliz que su rey, son elementos recurrentes en muchos cuentos populares de todo el mundo ${ }^{2}$. Sin embargo, en la tradición de las biografías de filósofos, lo que suele ponerse de relieve es una discusión sobre la dependencia del pensamiento filosófico respecto del poder y los poderosos, no solamente el poder de los tiranos ${ }^{3}$. El filósofo queda en estos casos clasificado claramente en dos categorías: o bien se enfrenta al tirano y consigue vencerlo o muere en el intento; o bien entre tirano y filósofo se establece una relación de parasitismo en que la dependencia es total y la biografía critica duramente la situación ${ }^{4}$.

${ }_{1}$ Para un análisis sistemático de la construcción de la imagen del tirano a partir de la caracterización del héroe mitológico, véase Catenacci 2012.

${ }^{2}$ Según la clasificación de Thompson 1955-1958, que recoge cuentos populares de todo el mundo. Los motivos que hemos desgranado aquí corresponden a sus números J816.1.1, H561.4, H583, J1675 y J1085.3, respectivamente.

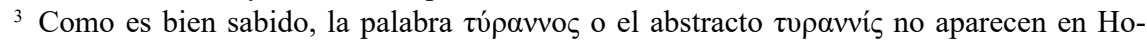
mero ni en Hesíodo: hay que esperar a Arquíloco (fr. 19 y 23 West $=22$ y 54 Tarditi) para su primera aparición en la literatura griega. Además, en las épocas arcaica y clásica, el término no está necesariamente mal connotado, sino que significa simplemente 'señor absoluto', envidiado por la masa de ciudadanos, sinónimo habitualmente de $\mu$ óv $\alpha \rho \chi 0 \varsigma$, uno que gobierna en solitario, y puede referirse a monarcas orientales, como Creso (Hdt. I 6), a sistemas autocráticos de diversas ciudades griegas, e incluso a Zeus mismo (por ejemplo en Esquilo, Pr. 10; 310). De hecho, la palabra misma sería ajena al griego, y se relaciona con orígenes orientales: para una síntesis de las principales hipótesis, véanse Giorgini 1993, pp. 45-48; Sánchez de la Torre 1994, pp. 157-160. Sobre las evoluciones de la figura del tirano en la Antigüedad, son especialmente útiles los volúmenes colectivos de Morgan 2003 y Lewis 2006.

${ }^{4}$ Conviene dejar claras de buen principio las bases metodológicas que regirán el presente análisis de las fuentes antiguas. Como es habitual en los estudios de los últimos decenios en el ámbito de la biografía antigua, no intentaremos en ningún caso dar cuenta de la historicidad real de las anécdotas o de las imágenes de los personajes que en ellas se construyen, ni de los contextos de producción de los textos que las incluyen, puesto que se trata de estudiar la tipificación de un elemento narrativo común a las biografías de los filósofos y su evolución a lo largo de la Antigüedad. Sirvan de referencia para este procedimiento las obras de Fairweather 1974 y 1983; Lefkowitz 1981 y 2009; Kivilo 2010; Grau 2010; Temmerman y Demoen 2016. 


\section{Filósofos que se enfrentan decididamente a tiranos y poderosos}

En el primer apartado despuntan ya algunos de los llamados Siete Sabios. Son bien conocidas las reyertas entre Solón de Atenas y el tirano Pisístrato: el sabio renunció a detentar él mismo la tiranía que el pueblo le brindaba de buen grado (D. L. I 49; Plu., Sol. 14.4-9) y denunció acto seguido ante la asamblea las pretensiones tiránicas de su pariente Pisístrato ${ }^{5}$ y a los atenienses que no hacían nada para impedírselo, por desconocimiento o por miedo, pero fue tratado de loco, porque los miembros del Consejo eran partidarios del tirano (D. L. I 49; Aristóteles, Ath. 14.2; Plu., Sol. 30.4). En el momento en que Pisístrato llegó efectivamente al poder tiránico, tal como Solón había presagiado, el sabio depuso las armas delante del cuartel general (D. L. I 50) y escapó al tirano mediante el exilio, aunque éste le ofrecía amistosamente que regresara a Atenas. Naturalmente, estas relaciones entre Solón y Pisístrato, que se manifiestan también en la tradición epistolar pseudoepígrafa (D. L. I 53-54 $)^{6}$, provienen, como es tan habitual en la biografía antigua, de la propia obra del poeta: constituyen, de hecho, la contextualización biográfica de los fragmentos 9 y 10 West, que el mismo Diógenes Laercio cita ${ }^{7}$. La oposición al poder tiránico por parte de Solón tiene, sin embargo, una tradición más amplia: durante su exilio en la corte del rey Creso se produce el célebre intercambio de preguntas y respuestas rápidas entre ambos, en las cuales éste muestra el carácter apotegmático y ácido habitual de las respuestas de los sabios a los tiranos ${ }^{8}$. El rey, como es bien sabido, pregunta a Solón de manera sucesiva quién es más feliz y quién ofrece un espectáculo de mayor belleza, pensando que él será el objeto de todas las respuestas, pero el sabio otorga el premio de

${ }^{5}$ De hecho, según Heraclides Póntico (apud Plu., Sol. 1.3), la madre de Solón era prima hermana de la madre de Pisístrato.

${ }^{6}$ Sobre el carácter marcadamente político y significativamente antitiránico de esta novela epistolar de sabios y filósofos que se ha conservado en los dos primeros libros de Diógenes Laercio, véanse Gómez 2002 y Junqua 2006.

7 Sobre este uso de las vidas de los autores para aclarar aspectos de sus obras, que sirven a la vez para ilustrar su vida, en un círculo cerrado autorreferencial, véanse Stuart 1931, Lefkowitz 1978, Lefkowitz 1981, pp. 88-90, Lefkowitz 2009, Kivilo 2010 y Temmerman y Demoen 2016.

${ }^{8}$ Los careos dialécticos de sabios y tiranos forman parte del acerbo primigenio del género de las preguntas y respuestas rápidas, que tanta influencia tendrán en la tradición cristiana posterior. Véase Jacob 2004. 
su consideración a Cléobis y Bitón, los dos jóvenes que murieron tras llevar a su madre al santuario de Delfos tirando ellos mismos del carro (Hdt. I 30-31), y a los faisanes y pavos reales, dotados por la naturaleza de todo su esplendor, mientras que la del rey es artificial (D. L. I 50-51; Hdt. I 29-33; Plu., Sol. 17.1-9). Esta oposición entre natural y artificioso o convencional, entre pv́øıৎ y vó $\mu$ os, forma parte también de las convenciones de los enfrentamientos entre los filósofos y los poderosos: el pensamiento del filósofo se mantiene libre e inalterable en sus convicciones sea cual sea su interlocutor. Solón se convierte de este modo en paradigma del sabio insobornable enfrentado al tirano en la defensa de sus convicciones, hasta el punto que incluso un tirano como Pítaco, por el simple hecho de que forma parte del grupo de los Siete Sabios, es presentado en la tradición biográfica como un derrocador del anterior tirano de Mitilene, Melancro (D. L. I 74; Suda s. u.), que toma el poder absoluto de la ciudad tras ser elegido democráticamente, sin violencia alguna ${ }^{9}$, y además lo devuelve al pueblo al cabo de diez años, una vez que los asuntos de la ciudad han vuelto a su cauce (D. L. I 75; D. S. IX 11, 2). Otro sabio que además es tirano presenta contradicciones mucho más interesantes: Periandro, el tirano de Corinto, mata a su esposa en un ataque de ira provocado por las acusaciones de sus concubinas, golpeándola con un taburete o de un puntapié, según otras versiones, exilia a su propio hijo (D. L. I 94) ${ }^{10}$, comete incesto con su madre (D. L. I 96) y acaba enloqueciendo completamente (Plu., Sept. conu. 146d). Por supuesto, el retrato encaja perfectamente en las concepciones habituales del tirano como un ser excesivo ${ }^{11}$, en la línea de las descripciones de Platón (R. 565d; 569b; 619bc), habida cuenta que el mismo Platón excluyó a Periandro de su lista particular de los Siete Sabios precisamente por ser tirano (Protágoras 343a4, cf. D. L. I 30), mientras que algunos eruditos antiguos planteaban la posibilidad de que existieran en realidad dos Periandros, sabio el uno y tirano el otro (D. L. I 98-99), para poder digerir mejor las contradicciones del personaje. Y, sin embargo, pesa más, como es habitual en la

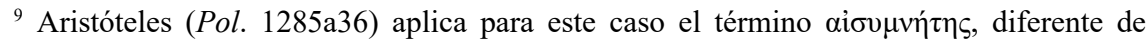

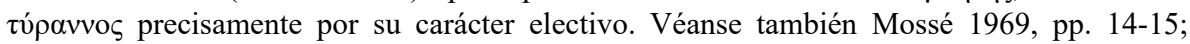
Cortina 1995.

${ }^{10}$ Las crueldades de Periandro aparecían ya en Heródoto III 50-53 y las recuerda también Pausanias II 28, 8.

${ }^{11}$ Véanse Yerli 1992 y Catenacci 2012. 
tipificación biográfica ${ }^{12}$, la imagen de los sabios como personajes partidarios de la democracia: una de las máximas que se le atribuyen es, ni más ni menos,

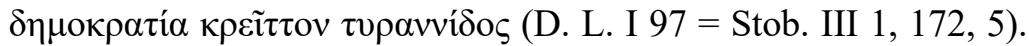

Siguiendo el mismo tópico antitiránico, Sócrates rechaza cualquier dependencia de los poderosos: se muestra altivo frente al rey Arquelao de Macedonia, y también frente a Escopas de Cranón y Euríloco de Larisa, no acepta sus regalos ni accede en ningún momento a visitarlos (D. L. II 25). Pero el enfrentamiento más célebre de la tradición biográfica antigua corresponde sin duda al que protagonizan Platón con Dionisio el Viejo, primero, y más tarde con Dionisio el Joven, tiranos de Siracusa (D. L. III 18-23; Olymp., In Alc. 97-112 Westerink). La construcción marcadamente tópica de estos enfrentamientos se manifiesta en todos los relatos: Platón entra en contacto con Dionisio el Viejo en el primero de sus viajes a Sicilia porque éste le fuerza a mantener una entrevista (D. L. III 18; Olymp, In Alc. 97 Westerink; Ath. 507b; Vita Platonis Anonyma 11 Westerink); en el segundo viaje quiso poner en práctica sus doctrinas políticas en un territorio que había de cederle el tirano, pero, finalmente, no lo obtiene y además corre riesgo de muerte por haber animado a Dión y Teódotas a liberar la isla (D. L. III 21); finalmente, por tercera vez viaja a Sicilia para reconciliar a Dión con Dionisio el Joven, pero regresa sin haber obtenido resultado alguno (D. L. III 23). Las motivaciones de los tres viajes, sin embargo, persiguen un objetivo muy claro: pretenden desmentir diversas acusaciones de la tradición biográfica negativa contra Platón ${ }^{13}$. Frente a las críticas que consideran que Platón era un glotón, ${ }^{14}$ capaz de viajar hasta Sicilia para gozar de las delicias de su famosa cocina ( más positiva insiste en que su viaje se debió puramente al deseo de contemplar los cráteres del Etna; los intentos de fundar una ciudad regida por sus ideas políticas, en el segundo viaje, son una respuesta a la tradición biográfica negativa que acusaba a Platón de no haber intentado poner nunca en práctica sus postulados teóricos (D. L. III 23); finalmente, los motivos aducidos para el tercer viaje buscan desmentir las acusaciones que pesaban sobre Platón de haber animado a su amigo Dión a liberar la isla de la tiranía sin

\footnotetext{
12 Véase Grau 2010.

${ }_{13}$ Así lo entiende también Riginos 1976, pp. 71-74.

${ }^{14}$ Véase, sobre estos ataques de la tradición biográfica a los filósofos por no practicar el ascetismo que predican, Grau 2019.
} 
hacer nada para evitar las represalias sobre é ${ }^{15}$. En todo caso, las biografías insisten en el hecho de que Platón jamás aceptó dinero ni bien alguno de los tiranos (Plu., De adul. et amic. 52f, Dio. 19.3), precisamente para desmentir a sus detractores, que lo acusaban de haber recibido toda clase de favores de parte de ellos y del mismo Dión (D. L. III 3, 9, 20) — de ser un parásito, en definitiva ${ }^{16}$-.

La continuación del relato es igualmente tipificada: Dionisio el Viejo comienza un diálogo con Platón a base de preguntas y respuestas que pretende la sumisión al tirano mediante el reconocimiento, por parte del filósofo, de su superioridad. Incluso una de las cuestiones es la misma que planteaba Creso a Solón: quién es el más feliz de los hombres (Olymp, In Alc. 97-112 Westerink). El carácter tópico de semejante intercambio resulta, pues, manifiesto. El sabio, naturalmente, se niega a esta sumisión y responde con absoluta $\pi \alpha \rho \rho \eta \sigma i ́ \alpha$. En el caso de Platón, su respuesta es coherente con su propia doctrina sobre el gobierno del sabio: jamás puede considerarse un bien supremo aquello que responde únicamente al interés de un solo hombre, excepto si este hombre sobresale por su virtud (D. L. III 18) ${ }^{17}$. El tirano, ofendido, pretende entonces matar a Platón, pero, tras la intercesión de Dión y Aristomenes, decide entregarlo a Pólide para que sea vendido como esclavo (D. L. III 19).

Naturalmente, las célebres escenas de los enfrentamientos dialécticos de Diógenes cínico con Alejandro Magno ${ }^{18}$ entrarían asimismo en este apartado

${ }^{15}$ Esta acusación, que puede inferirse de la misma Epistola XIII 362e, aparece enfatizada en Filóstrato, VA VII 2 y Eliano, VH III 17. Véase también Geffcken 1929, pp. 89-90.

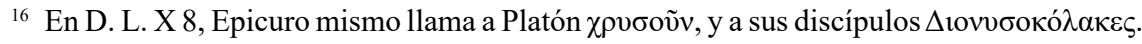

${ }^{17}$ La serie de preguntas y respuestas es más amplia en Olimpiodoro (In Alc. 113-115 Westerink), donde Platón trata abiertamente al tirano de cobarde. Su presencia en Phld., Acad. Hist., col. X 10-16 demuestra, en todo caso, que el tópico del enfrentamiento del filósofo con los tiranos forma parte del material biográfico más antiguo.

${ }^{18}$ Según Plutarco (Alex. 14.2-5, 671d-e), el comportamiento del cínico fue contrario al habitual de los políticos y filósofos de su época, que se afanaban por entrevistarse con el monarca. De hecho, Alejandro quedó, en la tradición biográfica, tan impresionado por las respuestas de Diógenes, que llegó a afirmar que, de no haber sido Alejandro, habría querido ser Diógenes (cf. también Plu., Alex. fort. uirt. 331d-332c). De Diógenes se decía igualmente (D. L. VI 45) que, frente a los que consideraban dichoso a Calístenes por gozar del lujo de Alejandro, él lo consideraba desdichado por almorzar y cenar cuando se le antojaba al monarca. El interés de Alejandro por la filosofía quedó, en todo caso, asociado a la figura biográfica del monarca: baste recordar que Onesícrito (FGrHist 134 T 2 y F 17, apud Str. $\mathrm{XV}$ 1. 63-65) fue enviado a dialogar con los gimnosofistas de Taxila, puesto que deseaba en- 
de filósofos que rechazan de plano el reconocimiento de la superioridad del poderoso, por su convencimiento de que la verdadera superioridad la otorga

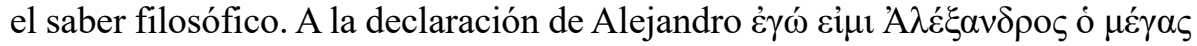
$\beta \alpha \sigma i \lambda \varepsilon v ́ \varsigma$, «Yo soy Alejandro, el gran rey», Diógenes responde denodadamen-

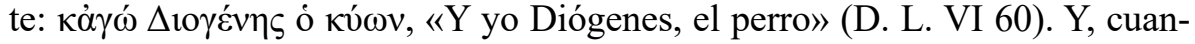
do Alejandro le pregunta si no tiene miedo de él, Diógenes lleva la cuestión, como suele suceder en este tipo de enfrentamientos, al terreno de los juegos

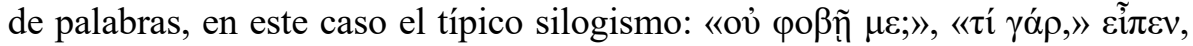

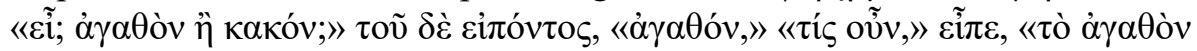
 A lo que dijo el monarca: «Un bien.» «Entonces -le espetó-, ¿quién va a temer un bien?» (D. L. VI 68). De hecho, Diógenes manifiesta con todos los poderosos que su dignidad personal es la misma, pero su libertad superior. Así, por citar sólo las anécdotas más significativas, hecho prisionero por Filipo tras la batalla de Queronea, el monarca preguntó a Diógenes quién era; él respondió

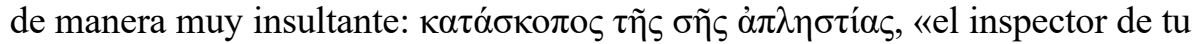
insaciabilidad», y Filipo quedó tan impresionado que lo dejó ir (D. L. VI 43). En otra ocasión, trata de miserable al mismo Alejandro y a su general Antípatro, mediante un juego de palabras malévolo a costa del mensajero, un tal

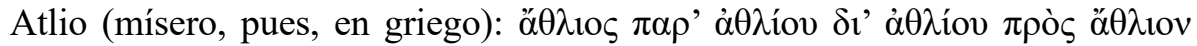
«mísera misiva de mísero a mísero, por vía de mísero» (D. L. VI 44). Tampoco Pérdicas escapa a su reproche; amenazado de muerte por el soberano si no

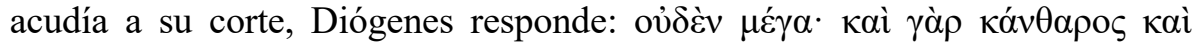

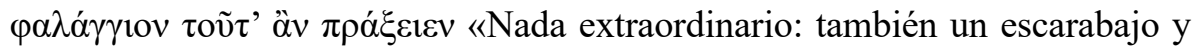
una tarántula podrían hacerlo» (D. L. VI 44). Contra los tiranos, las respuestas son aún más contundentes, y evidencian un odio sin matices a la tiranía. Así, a un tirano que le preguntaba cuál era el mejor bronce para hacerse una estatua, le respondió que aquel con que se habían hecho las de Harmodio y Aristogitón, los famosos tiranicidas (D. L. VI 50).

Existen, sin embargo, ejemplos mucho más cruentos de las reacciones violentas de un tirano ante la excesiva libertad de palabra de los filósofos.

\footnotetext{
tablar contacto con ellos movido por su fama, pero ellos exigían que fuera el monarca quien los visitara, lo que no habría sido decoroso para éste hacer personalmente. En cambio, en la novelada Vida de Alejandro del Pseudo-Calístenes, y en toda la tradición medieval que bebe de ella, es el monarca mismo quien se entrevista con los gimnosofistas, y su diálogo reviste tintes claramente filosóficos.
} 
Zenón de Elea, que había proyectado matar al tirano Nearco —o Diomedonte, según otras fuentes-, fue arrestado e interrogado a propósito de sus cómplices; él denunció a todos los amigos del tirano para aislarlo completamente y, a continuación, tras anunciar que deseaba comunicarle unos detalles al oído, el tirano se le acercó y el filósofo se lo mordió tan fuerte que no pudieron separarlo hasta que lo hubieron molido a golpes (D. L. IX 26), aunque otras fuentes afirman que lo que le mordió con tanto ahínco fue la nariz (D. L. IX 27). Según otra versión, interrogado por el tirano, lo insulta y provoca a los presentes acusándolos de cobardía, hasta que termina por cortarse la lengua con los dientes y escupirla a la cara de su inquisidor, de manera que los ciudadanos, alentados por semejante ejemplo, lo lapidan (D. L. IX 27). Esta última versión, en realidad, es una contaminación evidente con la tradición del enfrentamiento de otro filósofo, Anaxarco de Abdera, con el tirano de Chipre, Nicocreonte: capturado tras ser lanzado contra su voluntad a las costas de Chipre durante un viaje por mar, Nicocreonte lo condena a morir, pero Ana-

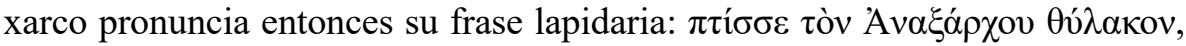

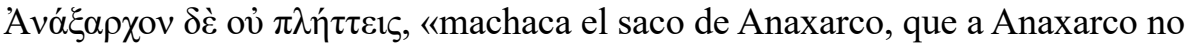
lo dañas ${ }^{19}$. El tirano ordena entonces que le corten la lengua, pero es el mismo Anaxarco quien se la corta con sus propios dientes y se la escupe a la cara (D. L. IX 59). Resulta difícil, naturalmente, saber con certeza cuál de las dos biografías presentó por primera vez este relato, pero parece plausible que la imagen tópica pasase de la vida de Anaxarco, donde encaja perfectamente, a la de Zenón, donde no tiene tanto sentido ${ }^{20}$. Anaxarco, además, ya había dejado bien clara su disposición a no subyugarse a autoridad alguna cuando le hizo ver a Alejandro Magno que lo que fluía de una herida del monarca no era el

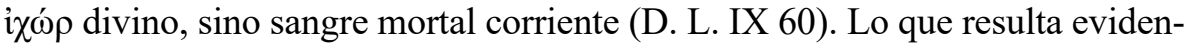
te es que se trata de una variante del tópico inicial, que analizábamos en las vidas de Solón y de Platón, donde el enfrentamiento con el tirano de desarrolla de un modo exclusivamente dialéctico, mientras que aquí el filósofo paga con la propia vida su libertad de expresión, simbolizada contundentemente en la potente imagen de la lengua arrancada y escupida a la cara del tirano. Ambos, Zenón y Anaxarco, entrarían en el grupo de los que podríamos llamar «mártires de la filosofía», a quienes la defensa de su libertad de pensamiento

${ }^{19}$ Cabe recordar, en este punto, que Diógenes cínico afirmaba de Dionisio el Joven que

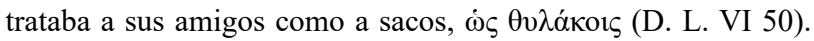

20 Véanse Bernard 1984 y Dorandi 1994. 
y la filosofía que predican les lleva a la muerte a manos de los poderosos, al estilo de los posteriores mártires cristianos ${ }^{21}$.

El esquema completo de los enfrentamientos entre filósofos y tiranos podría resumirse, en todo caso, como sigue:

1. El filósofo va a la corte del tirano siempre forzado, ya sea conducido mediante violencia, o bien porque el filósofo no puede negarse a visitarlo. Jamás, sea como fuere, el filósofo accede a ir por gusto, sino que a menudo rechaza de entrada la invitación.

2. El tirano pretende obligar al filósofo a reconocer su superioridad personal y la del régimen autocrático que practica, habitualmente a través de un diálogo con preguntas y respuestas, pero el filósofo no se doblega y sostiene su oposición al despotismo con total libertad de palabra.

3. El tirano se ofende enormemente y responde con una dosis de violencia que varía de una biografía a otra, con formas narrativas que van desde el exilio a la muerte violenta.

A partir de este esquema básico, aparecen a veces en las diversas biografías algunos elementos aislados: el filósofo se limita a tomar partido contra los poderosos, o no acepta sus regalos ni someterse a ellos, ni quiere visitarlos en sus cortes, o bien la biografía se centra tan solo en los diálogos entre filósofos y tiranos, que forman parte ineludiblemente de estos relatos ${ }^{22}$.

Raramente, en cambio, el filósofo se convierte en tiranicida. Conocemos únicamente el caso de Heraclides Póntico, aunque no se especifica ni siquiera el nombre el tirano del cual liberó su patria (D. L. V 89); además es posible que este caso único sea en realidad una confusión de Diógenes Laercio con un homónimo de Heraclides, discípulo de Platón, famoso precisamente por haber dado muerte a Cotis I, rey de los ódrisas, el 359 a. $\mathrm{C}^{23}$.

${ }^{21}$ Véase Grau y Narro 2013, p. 78: «Sin duda, estas narraciones comparten con los Acta martyrum cristianos el gusto por los detalles morbosos, el comportamiento desafiador de los torturados, las respuestas lapidarias en la hora fatal, e incluso una cierta antropología difusa compartida que separa cuerpo y alma, con ascensión celeste incluida». Estas similitudes ya fueron apuntadas por Simonetti 1956, Ronconi 1966 y Ricci 1964.

${ }^{22}$ Para las formas narrativas concretas de estos diálogos, véase Grau 2009.

${ }^{23}$ La cita laerciana proviene de los Homónimos de Demetrio de Magnesia, lo cual aún daría más opciones a la hipótesis de que se trate de una confusión entre ambos personajes. 
Caso aparte, como en tantos otros aspectos, es el de Pitágoras. Según la tradición biográfica, tuvo conflictos con Polícrates, el tirano de Samos, huyendo del cual llegó a Crotona, precisamente (D. L. VIII 3), aunque, según Jámblico (VP 28), el filósofo se fue de Samos porque sus habitantes no estaban muy predispuestos a aprender, y no por culpa del tirano, como deja entender Diógenes Laercio. Según Porfirio (VP 7-9), fue Polícrates quien había recomendado al filósofo por carta a Amasis, rey de Egipto, cuando éste se dirigió allí en el curso de sus viajes, de manera que Pitágoras habría sido al principio un protegido del tirano, hasta que se le opuso, a su regreso a Samos, y tuvo que exiliarse en Crotona, donde desarrolló su respuesta política. De hecho, Heródoto (III 45) nos informa de un complot contra el tirano inducido por los samios que el mismo Polícrates había mandado a Egipto: los biógrafos bien podrían haber incluido por ello a Pitágoras en este episodio.

\section{Filósofos parásitos y aduladores}

En la otra cara de la moneda, algunos filósofos son acusados abiertamente por la tradición biográfica de depender de los poderosos, empezando por el sabio Periandro, tirano él mismo, que fue huésped de Trasíbulo, el tirano de Mileto (D. L. I 95; Hdt. I 20). Jenofonte, por supuesto, fue invitado por Ciro a su corte a través de un amigo suyo, de nombre parlante Próxenos; pidió consejo a Sócrates, que le exhortó a consultar el oráculo délfico, pero Jenofonte no preguntó al oráculo si le convenía o no visitar al gran rey, sino cómo debía ir, cosa que provocó el enojo del maestro y engendró la amistad con Ciro que llevaría a la Anábasis (D. L. II 49-50). En realidad, toda la narración proviene punto por punto de la obra de Jenofonte (An. III 1.4-7), como es habitual en las biografías antiguas $^{24}$. Igualmente, la biografía afirma que dotó de mercenarios de Ciro al rey espartano Agesilao, con quien mantenía una gran amistad, cosa que indujo a los atenienses a exiliarlo por filolaconismo (D. L. II 51), una información extraída también de la Anábasis (V 3.6), y del panegírico que Jenofonte dedicó al rey (D. L. II 57). Sea como fuere, la tradición biográfica interpreta muy negativamente las buenas relaciones de los filósofos con los poderosos.

\footnotetext{
${ }^{24}$ A los estudios, ya citados, de Stuart 1931, Lefkowitz 1978, Lefkowitz 1981, pp. 88-90, Lefkowitz 2009, Kivilo 2010 y Temmerman y Demoen 2016, hay que añadir, para los filósofos, Chitwood 2004 y Grau 2010.
} 
El caso paradigmático es el de Esquines el socrático, quien es duramente criticado por haber accedido a ir a la corte del tirano Dionisio el Joven de Siracusa, a causa de su extrema pobreza (D. L. II 61), que le lleva incluso a ofrecerle al tirano sus diálogos a cambio de regalos (D. L. III 36). Y, de hecho, la tradición más antiplatónica presenta a Platón al mismo nivel de adulación del tirano que su condiscípulo Esquines, a quien habría introducido en la corte siracusana (Plu., De adul. et amic. 67c-e). Queda claro, en todo caso, que el tópico de las relaciones de filósofos y tiranos está supeditado al contraste entre ascetismo y deseo de riquezas o pi $\lambda \alpha \rho \gamma v \rho i ́ \alpha$. El ejemplo más conspicuo, en este sentido, es el del modelo más opuesto al ascetismo filosófico en la tradición biográfica ${ }^{25}$, Aristipo de Cirene, otro socrático, que adula sin tasa a los tiranos a cambio de poder compartir sus lujos. Aristipo es una especie de paradigma de filósofo parásito de tiranos, una posición que defiende ante todo vituperio de sus opositores, como cuando, en una anécdota célebre y repetida ${ }^{26}$, Diógenes cínico le espeta, mientras lavaba sus verduras: $\varepsilon \hat{i}$

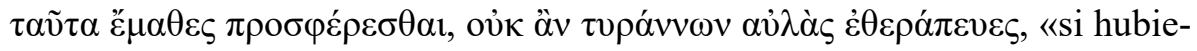
ras aprendido a vivir con esto, no tendrías que andar buscando los palacios de los tiranos», y Aristipo responde, dándole la vuelta con su habitual inge-

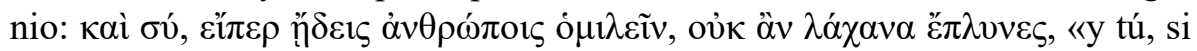
supieras tratar con los hombres, no tendrías que andar limpiando verduras» (D. L. II 68). Ante el mismo Dionisio, que le pregunta por qué se le acerca,

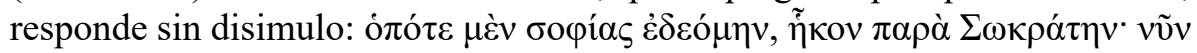

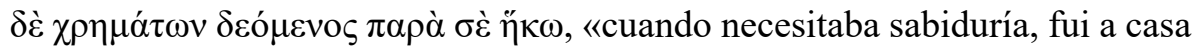
de Sócrates; ahora que necesito dinero, vengo a tu casa» (D. L. II 78). Al pedirle dinero, Dionisio le recuerda que a los filósofos no les faltan recursos, pero Aristipo le pide que le dé el dinero para examinar después la cuestión;

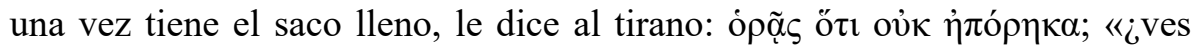
cómo no me han faltado recursos?» (D. L. II 82). También es frecuente en la vida de Aristipo el contraste con Platón, con quien se le hace coincidir en la corte de Dionisio: un día que el tirano ordena a los que banquetean que se vistan de púrpura y dancen, Platón se niega, pero Aristipo accede sin pudor

25 Véase Grau 2019.

${ }^{26}$ Se trata, en efecto, de una anécdota recurrente en las biografías de los filósofos, que pretende contrastar el ascetismo de unos y la vida lujosa de otros: valgan de ejemplo los pasajes de D. L. II 102 (entre Teodoro de Cirene, apodado el ateo, y Metrocles el cínico), VI 58 (donde el papel de Aristipo lo hace Platón) y Horacio, Ep. I 17.13-32. 
alguno, a través de un intercambio, además, de versos de la Bacantes de Eurípides (D. L. II 78). Idéntico contraste se produce cuando Aristipo acepta el dinero del tirano y Platón sólo un libro; la respuesta de Aristipo sigue el

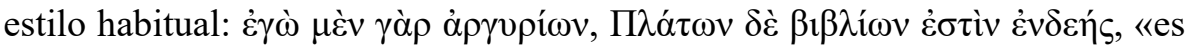
que yo estoy necesitado de dinero, y Platón, en cambio, de libros» (D. L. II 81). El caso más escandaloso, sin embargo, sucede en una ocasión en que Aristipo pide un favor al tirano para un amigo suyo y, para ser escuchado, se lanza a sus pies; criticado duramente por semejante actitud de absoluto ser-

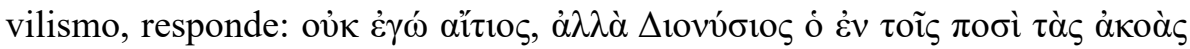
ह̌ $\chi \omega v$, «no soy yo el culpable, sino Dionisio, que tiene los oídos en los pies» (D. L. II 79). Aristipo, pues, queda configurado en la tradición biográfica como el adulador de tiranos por antonomasia, sin duda por el afán de lujos que se le atribuye, aunque cabe señalar que alguna de estas anécdotas de parasitismo descarado en otras fuentes, como en D. L. II 82, se le asigna a Platón, de manera que cabe pensar que se produjo un trasvase de uno a otro filósofo, y ambos debían recibir las mismas críticas de parásitos en la tradición biográfica.

Otra figura igualmente denigrada por la tradición biográfica por idénticos motivos es Epicuro: a partir del simple hecho de que le dedicó un tratado (D. L. X 28), la biografía hace de él un adulador vergonzante de Mitres, el ministro del rey de Tracia, Lisímaco, a quien en sus cartas llama «salvador» y «señor» (D. L. X 4). Se trata, por supuesto, de una lectura malévola de las propias obras del filósofo, como es habitual en las biografías antiguas, sin más fundamento ${ }^{27}$. Dedicar libros a un poderoso está particularmente mal visto en la tradición biográfica, como forma servil de adulación: Aristipo, por ejemplo, dedica diversas obras a Dionisio (D. L. II 84), de manera que no es de extrañar que se le presente como un adulador sin tasa del tirano; lo mismo hizo Euclides con el rey Antígono Gónatas (D. L. II 110), Jenócrates con Alejandro Magno (D. L. IV 14) y Timón con Antígono y Tolomeo II Filadelfo (D. L. IX 110). En realidad, basta que el filósofo visite a un poderoso o acepte sus regalos para que la biografía lo denueste sin contemplaciones, como ocurre con Estilpón, que fue acogido en la corte de Tolomeo Soter, quien le dio dinero y lo invitó a embarcarse

${ }^{27}$ De hecho, la fuente de esta acusación, como de casi todas las demás, es Timócrates, responsable de prácticamente toda la tradición biográfica negativa contra Epicuro. 
con él hacia Egipto; Estilpón toma el dinero, aunque se niega a viajar con él (D. L. II 115), pero su posición es ambigua por este motivo. Cuando, más tarde, Demetrio Poliorcetes toma Mégara, su ciudad, respeta la casa de Estilpón, como Alejandro Magno había respetado en Tebas la de Píndaro, seguramente siguiendo el mismo tópico ${ }^{28}$. Es entonces cuando el rey le restituye sus bienes y Estilpón responde que nadie le ha podido quitar sus posesiones, que son la cultura, la razón y los conocimientos, comportándose en este punto como corresponde a un filósofo en las biografías positivas. Menedemo de Eretria se relaciona con los poderosos sin mengua de su dignidad, obteniendo beneficios para su ciudad, como cuando consiguió una importante reducción de los impuestos (D. L. II 140) y el rey Antígono se proclamó discípulo suyo (D. L. II 141). Sin embargo, la tradición biográfica no suele perdonar los deslices de adulación a los poderosos de los filósofos, por leves que sean: Antígono envió a Bión de Borístenes un par de esclavos cuando éste estaba postrado por la enfermedad, y sólo por este motivo se afirma, con fina y ácida ironía, que, al final de su vida, Bión siguió a Antígono... en litera (D. L. IV 54) ${ }^{29}$. Sin embargo, Teofrasto fue recibido por la reina Casandra y Tolomeo Soter le envió un mensajero (D. L. V 37), Ésfero habitó un tiempo en la corte de Tolomeo Filopátor, en Alejandría, donde tenía discusiones con el monarca acerca de si el sabio podía tener opiniones (D. L. VII 177), y Timón fue familiar del mismo Antígono y también de Tolomeo II Filadelfo (D. L. IX 110), sin que, en ninguno de estos casos, pueda inferirse crítica alguna por parte de los biógrafos.

\section{Filósofos y poetas en su relación con los poderosos}

Resulta particularmente instructivo contrastar este esquema narrativo con el de otras biografías de operadores culturales antiguos donde las relaciones con tiranos y poderosos ocupan asimismo un lugar destacado, como son las

${ }^{28}$ A estos ejemplos podría añadirse también el pasaje de D. L. VI 88 según el cual Alejandro Magno habría respetado la casa de Crates en Tebas, si interpretamos el texto, que está patentemente corrupto, como lo hacía H. Diels: véase el aparato crítico ad locum de la edición de Dorandi 2013. Sea como fuere, Alejandro le habría ofrecido a Crates reconstruir la ciudad de Tebas, a lo cual él respondió que no le interesaba, porque vendría otro Alejandro a destruirla de nuevo (D. L. VI 93).

${ }^{29}$ Sobre las relaciones de Bión y Antígono, véase Fuentes González 2003, p. 64. 
vidas de los poetas ${ }^{30}$. Por ejemplo, Arión, el mítico inventor del ditirambo, estuvo al servicio de Periandro (Hdt. I 23-24). Este prejuicio popular empieza a manifestarse en el momento en que el poeta va dejando de ser un maître de $v^{2}$ rité $^{31} \mathrm{y}$ aparece la figura de los poetas cortesanos, como Anacreonte o Íbico, vinculados a la corte de Polícrates de Samos y después a los Pisistrátidas áticos (Hdt. III 121) ${ }^{32}$. Y Píndaro, naturalmente, celebró las victorias de Hierón de Siracusa y Terón de Agrigento, para quienes no escatimó elogios $(O$. I 11-16; $O$. II 5-11; $P$. III 85). El caso más emblemático, en este sentido, es el de Simónides, acusado a menudo en la tradición biográfica de $\alpha i \sigma \chi \rho о \kappa \varepsilon ́ \rho \delta \varepsilon 1 \alpha$

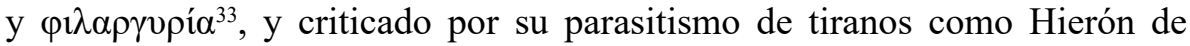
Siracusa $^{34}$, con tópicos muy similares a los que hemos analizado aquí en las biografias de diversos filósofos: aceptó regalos y grandes sumas de dinero de Hiparco a cambio de permanecer a su lado (Platón, Hipparch. 228c), y accedió a componer un poema en honor de Anaxilao, vencedor en una carrera de carros tirados por mulas, a pesar de haberse negado en un principio por la escasa dignidad de semejantes animales, tan pronto como el tirano subió el precio (Aristóteles, $R h .1405$ b). Incluso un apotegma atribuido a Aristipo por Diógenes Laercio, en que el filósofo afirma que los sabios se acercan a las puertas de los ricos, pero nunca al contrario (D. L. II 69), es puesto en boca de Simónides por la tradición proverbial (Gnomol. Par. 142). Más tarde, es frecuente que los poetas, como Teócrito y Calímaco, aparezcan vinculados a las cortes helenísticas, lo mismo que sucede con los filósofos a partir de Aristóteles, como hemos visto ${ }^{35}$.

Filósofos y poetas son tratados, pues, de manera similar por la tradición biográfica en sus relaciones con los poderosos, que acostumbran a connotarlos negativamente, aunque la crítica afecta más a los filósofos que a los

30 Para un análisis más detallado de este tema, remitimos al estudio de Jufresa y Fau 2007.

31 Por usar la clásica expresión de Detienne 1967.

32 Es todavía muy instructivo, para el estudio de estas nuevas relaciones con el poder de los intelectuales en general y de los poetas en particular, el análisis de Gentili 1984 [1996], p. 339 ss.

33 Un buen ejemplo son los versos de la Paz de Aristófanes (695-696), donde leemos, a

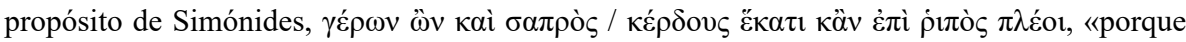
estando como está, viejo y chocho, por dinero navegaría hasta sobre una zarza» [trad. L. M. Macía Aparicio]. Para toda la tradición biográfica relativa a Simónides, véase Bell 1978.

34 Por ejemplo, en Pl., Ep. 311a, Ath. 656d, Ael., VH IX 1.

35 Para un elenco de estos «filósofos cortesanos», véase Jocelyn 1977, pp. 350-351. 
poetas: los mejores connotados por sus biógrafos son aquellos que rechazan las ofertas de los poderosos de visitarlos y hacerles la corte, particularmente por el ascetismo y las aspiraciones de libertad total, de insobornable $\pi \alpha \rho \rho \eta \sigma i ́ \alpha$, que predican en sus doctrinas.

\section{Evoluciones del tópico en la Antigüedad Tardía, pagana y cristiana}

El enfrentamiento del buen filósofo, asceta y libre, con el poderoso, tiránico y lujurioso, queda constituido de este modo como un elemento biográfico habitual; así lo manifiesta Filóstrato al principio del libro VII de su Vida de Apolonio de Tiana, en una especie de declaración universal de lo que signi-

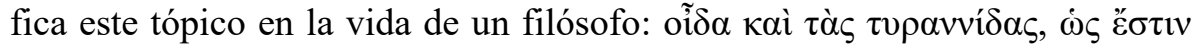

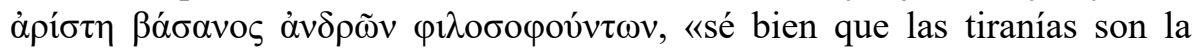
mejor piedra de toque para los hombres que se dedican a la filosofía». Y, a continuación, rememora largamente el listado de los filósofos de la Antigüedad que mantuvieron relaciones con los poderosos, con palabras elogiosas para quienes de entre ellos resistieron la tortura por no renunciar a sus ideales de libertad; los ejemplos son los que ya nos son conocidos por la tradición, de donde Filóstrato sin duda toma sus datos (VII 2-3): Zenón de Elea con Nearco, Platón con Dionisio, Calístenes de Olinto, Diógenes y Crates con Alejandro, Heraclides y Pitón, asesinos de Cotis el tracio, pero también otros personajes habituales de la biografía helenística, como Fitón y Dionisio (cf. D. S. XIV 108). Todo ello como antecedente erudito, tan típico de Filóstrato, al enfrentamiento del mismo Apolonio de Tiana con el emperador Domiciano, definido como un acontecimiento de mayor envergadura porque los otros eran gobernantes de pequeños territorios, mientras que Apolonio se enfrentó al emperador del mundo (VII 3-4), aunque su oposición sigue exactamente los cánones del tópico biográfico que hemos expuesto aquí, incluso con un período en prisión (VII 22-28) y un intercambio dialéctico con el emperador (VII 29-35), que es caracterizado tipificadamente como tirano (VII 14). El incidente acaba, de hecho, con la desaparición milagrosa de Apolonio (VIII 8-10), pero el emperador se muestra más bien convencido de la bondad del hombre divino. El enfrentamiento de filósofo y tirano se convierte así en un ingrediente que no puede faltar en las biografías antiguas para connotar positivamente a sus protagonistas, tal como lo define un discípulo de Apolonio, Demetrio, consultado por éste sobre lo más conveniente en relación con el emperador (VII 12): 


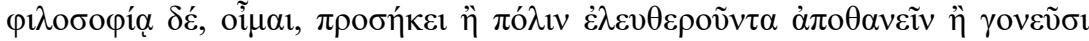

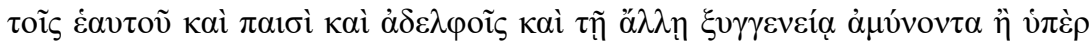

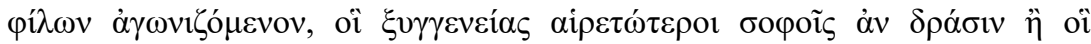

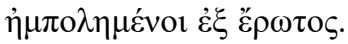

Y es que a la filosofía le es adecuado, creo, o bien morir por liberar una ciudad o por defender a los padres, hijos, hermanos y el resto de la familia, o combatiendo por los amigos, que para los hombres sabios son más estimables que el parentesco, o por los que han conquistado por amor. [Trad. A. Bernabé]

De ahí, seguramente, el interés de Jámblico y Porfirio, prácticamente contemporáneos tanto de Filóstrato como de Diógenes Laercio, en la segunda mitad del siglo III $^{36}$, por presentar a Pitágoras y a los pitagóricos perseguidos y amenazados por tiranos y poderosos. Jámblico, sin embargo, relata la huida de Pitágoras del tirano Polícrates con tintes bastante vagos (VP 11):

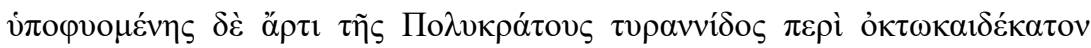

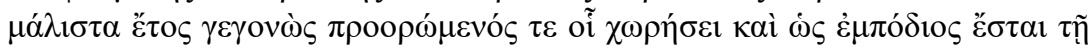

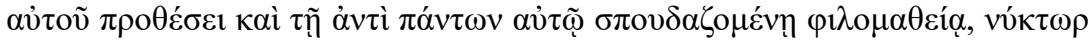
$\lambda \alpha \theta \dot{\omega} v \ldots . . \delta \varepsilon \pi \hat{o} \rho \theta \mu \varepsilon v \varepsilon$.

Cuando apenas comenzaba la tiranía de Polícrates, Pitágoras que contaba a la sazón dieciocho años de edad, previó hacia dónde se habría de encaminar y qué gran obstáculo sería para sus intenciones y para su amor por el estudio, en el que se esforzaba por encima de todas las cosas. Así que de noche y en secreto ... se marchó. [Trad. D. Hernández de la Fuente]

Las razones expuestas parecen más bien una simple conexión entre la subida al poder del tirano y la huida del filósofo, con el fin de evidenciar su desaprobación del nuevo régimen y su predilección por la democracia, tal como manifiestan también sus consejos políticos ${ }^{37}$, en la línea del tópico

${ }^{36}$ La obra de Filóstrato suele datarse a principios del siglo III, no mucho después del 217: cf. Solmsen 1940. La datación para Diógenes Laercio, a su vez, aunque más discutida, tiende a situarse como muy tarde a mediados también del siglo III: cf. Runia 1997, col. 601; Mejer 1994, p. 832. Y Porfirio y Jámblico pertenecen ambos, como es bien sabido, al mismo siglo

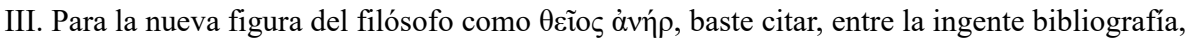
aparte de los estudios clásicos de Bieler 1935-1936, Brown 1971, Fowden 1982 y Cox 1983, los más recientes de Anderson 1994 y Du Toit 1997. Para un estado de la cuestión con actualización bibliográfica y un excelente planteamiento del problema, véase Alviz Fernández 2016.

${ }^{37}$ En particular, la isonomía o igualdad de todos los ciudadanos propuesta en Vit. Pyth. 46. 
biográfico que hemos ido desgranando hasta aquí. De hecho, su descripción del carácter tiránico es la tradicional, tal como la recordábamos más arriba, referida a Periandro (Iambl., VP 78):

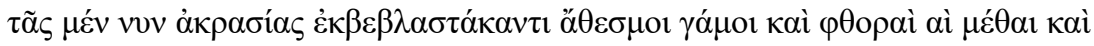

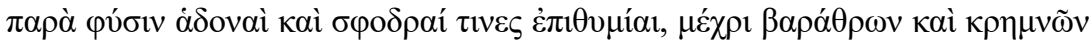

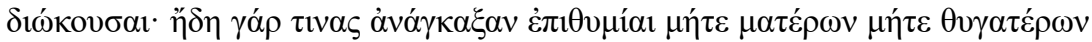

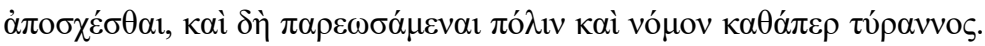

De la intemperancia nacen los matrimonios ilegítimos, la corrupción, la embriaguez, los placeres contra natura y algunos deseos apasionados que llevan a abismos y precipicios. Pues estos deseos han forzado a algunos a no abstenerse de la unión con madres o hijas, contraviniendo las regulaciones ciudadanas y las leyes como un tirano. [Trad. D. Hernández de la Fuente]

El contraste fuerte con un tirano, en cambio, lo protagoniza Pitágoras contra Fálaris, en un largo episodio, aunque Jámblico señala que se trata sólo de un caso concreto que manifiesta la actitud general antitiránica del filósofo (VP 214-220):

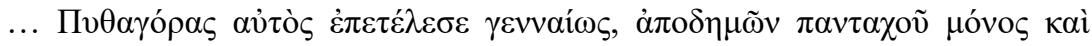

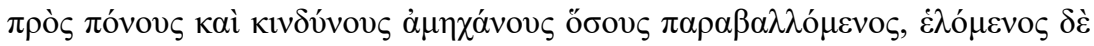

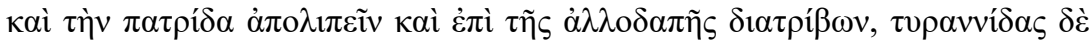

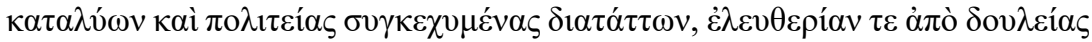

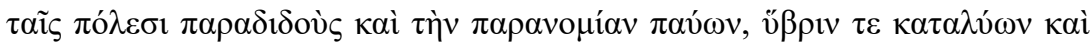

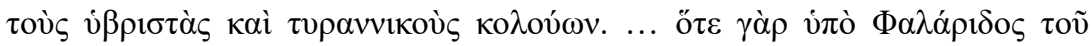

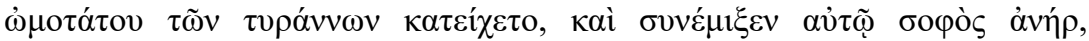

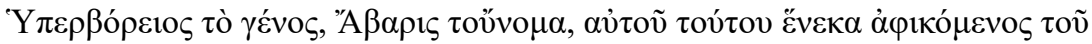

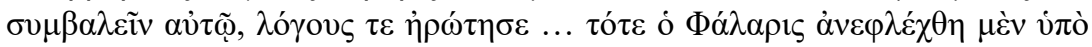

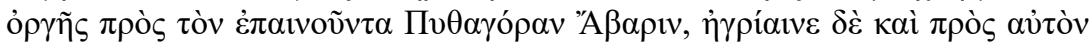

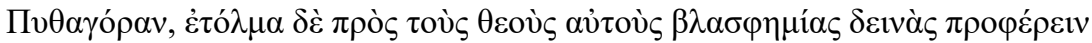

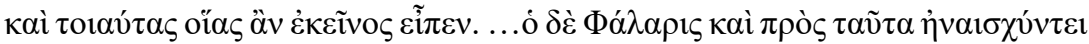

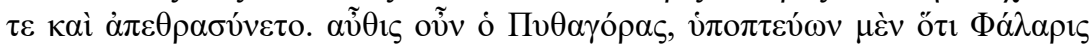

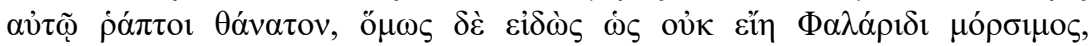

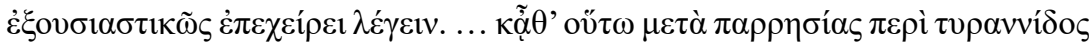

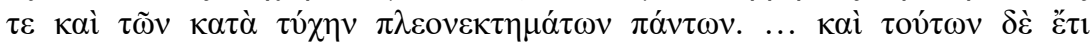

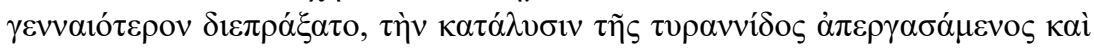

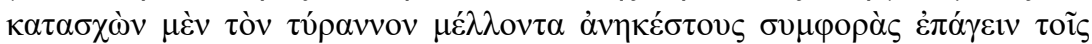

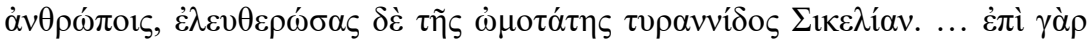

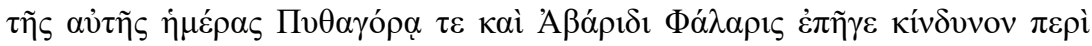

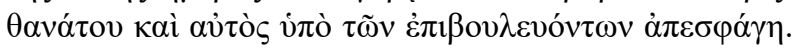


... El propio Pitágoras se comportó noblemente cuando viajó por todas partes en soledad y arrostró fatigas y peligros imposibles, eligiendo abandonar su patria y pasando el tiempo en tierra extraña. También cuando abolió tiranías, puso en orden constituciones caóticas y liberó ciudades de la esclavitud. Puso fin a la ilegalidad y neutralizó la insolencia impidiendo que los tiranos insolentes actuaran. ... Cuando fue capturado por Fálaris, el más cruel de los tiranos, le visitó un sabio de estirpe hiperbórea, que se llamaba Abaris, que había llegado para frecuentar su compañía y preguntarle sobre diversos asuntos. ... Fálaris montó en cólera con Abaris, que había elogiado a Pitágoras, y concibió gran odio hacia el propio Pitágoras, atreviéndose a proferir terribles blasfemias contra los propios dioses, que solamente alguien como él podría pronunciar. ... Fálaris se mostraba contrario con argumentos vergonzosos y osados, con que Pitágoras, sospechando que Fálaris planeaba su muerte, pero sabedor que no era su destino morir en sus manos, emprendió un discurso lleno de autoridad. ... Y en virtud de todo ello, habló haciendo uso de la libertad de palabra sobre la tiranía y las ventajas de la suerte. ... Pero hizo algo aún más noble que todo esto, pues consiguió la abolición de la tiranía, refrenando al tirano cuando éste iba a procurar desgracias irremediables sobre sus ciudadanos y liberando Sicilia del despotismo. ... Justo el mismo día en que Fálaris amenazó a Pitágoras y Abaris con la muerte, él mismo cayó asesinado víctima de conspiradores. [Trad. D. Hernández de la Fuente]

Por supuesto, el episodio es una pura construcción literaria: se ha integrado en la biografía de Pitágoras seguramente porque Fálaris, el célebre tirano de Agrigento de la primera mitad del siglo VI a.C., se había convertido en un paradigma de crueldad (cf. Pi., P. I 95-96). El desenlace, en todo caso, es un tiranicidio en toda regla, que, por tanto, glorifica al filósofo.

Quienes sí son perseguidos, en cambio, y de la forma más cruenta, son algunos de los pitagóricos, como la pareja formada por Milias y Timica, un relato que conocemos por Jámblico (VP 189-194) y Porfirio (VP 61), quienes citan a su vez como autoridades a Hipóboto (fr. 19 Gigante) y a Neantes (FGrHist $84 \mathrm{~F} 31 \mathrm{~b}$ ). Porfirio se limita a mencionar sus nombres, puesto que en ese punto, precisamente, se acaba el texto que nos ha transmitido la tradición manuscrita. Jámblico, en cambio, se entretiene larga y novelescamente a relatar los pormenores de la emboscada que los enviados del tirano tienden a los pitagóricos y del diálogo que ambos mantienen con Dionisio sobre la célebre y misteriosa prohibición de las habas, hasta el desenlace final con Timica (VP 194): 


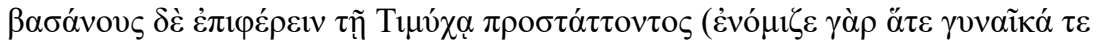

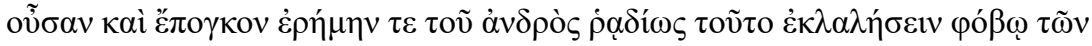

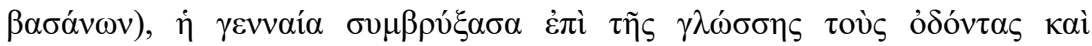

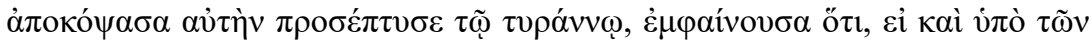

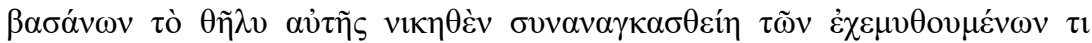

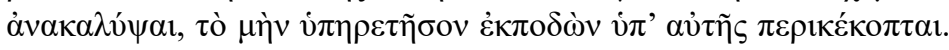

Dionisio sometió a tortura a Timica (pues pensaba que siendo mujer y estando embarazada y privada del marido se lo contaría más fácilmente que él por miedo al suplicio). Pero la valiente se cortó la lengua de un mordisco y se la escupió al tirano, mostrando que incluso si por las torturas su feminidad era vencida y se la obligaba a revelar alguno de los secretos, el órgano que serviría para ello estaría cortado de raíz. [Trad. D. Hernández de la Fuente]

La anécdota biográfica mezcla, pues, el tópico de la resistencia de los filósofos ante la tortura ejercida por los tiranos, en la línea de Anaxarco y Zenón de Elea que comentábamos anteriormente, incluido el detalle de la lengua cortada, con el tópico, menos cruento, de la negativa de los sabios a visitar a los poderosos y entrar en relaciones de amistad con ellos, omnipresente en la tradición biográfica.

Una variante, esta vez con final feliz, de este mismo relato tipificado, se produce cuando el mismo tirano Dionisio, para probar si son ciertas las acusaciones de algunas personas de su entorno, pone a prueba a los pitagóricos Fintias y Damón: hace creer a Fintias que está condenado a muerte por conspirar contra él, y éste le ruega que retenga a su amigo Damón, otro pitagórico, a su lado, mientras él ordena sus asuntos antes de someterse al castigo; ante la estupefacción general, Damón acepta el trueque y, para estupor aún mayor, Fintias regresa al final del día a cumplir con la pena, con lo que se demuestra palmariamente que la célebre amistad pitagórica es algo más que palabrería, y el mismo tirano besa a los dos filósofos y les pide que le incluyan entre sus amigos, a lo cual, por supuesto, ellos se niegan (Aristox., Fr. 31 Wehrli, apud Iambl., VP 234-237).

Quien no tuvo tan buen trato fue, en cambio, Cilón, un crotoniata ilustre,

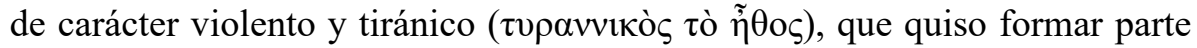
de la escuela $\mathrm{y}$, despechado por su rechazo, persiguió con sus partidarios a todos los pitagóricos, incendió su casa (o la casa de Milón, donde estaban reunidos) con los discípulos dentro, y provocó la huida - según algunas versiones, incluso la muerte - del propio maestro (D. L. VIII 39; Plu., Gen. Socr. 583a-c; Iambl., VP 248-250; Porph., VP 54-57). 
En claro contraste con la importancia que reviste el tópico de la persecución por parte de los tiranos, con marcados visos cruentos, según hemos visto, en la biografía helenística y en las obras que la toman como fuente, muy significativamente cabe destacar la ausencia total de este tópico bien consolidado en las Vidas de filósofos y sofistas de Eunapio de Sardes, ya a finales del siglo IV ${ }^{38}$. Si acaso, a lo largo de la obra, lo que flota, por así decir, en el ambiente, es el peligro de ser perseguido por la autoridad imperial por practicar abiertamente la teúrgia, percibida como una actividad mágica, pagana y perniciosa, que puede llevar incluso a la condena a muerte: ese es el motivo de que Edesio, por ejemplo, no hiciera ostentación pública de sus capacidades taumatúrgicas (VS VI 1.5), no fuera a tener problemas con el emperador Constantino, cuya política era marcadamente antipagana y favorable a los cristianos ${ }^{39}$. Sin embargo, la única anécdota biográfica de persecución real por parte de la autoridad es la condena de Sópatro de Apamea el 337, acusado, tras un complot de cortesanos, de haber detenido una flota cargada de trigo mediante el uso de la magia; una acusación que, además, es comparada expresamente con la condena de Sócrates (VS VI 2.7). Es evidente, en todo caso, que, a pesar de los esfuerzos retóricos de Eunapio, la comparación no funciona en modo alguno y el relato no sigue en absoluto los tópicos habituales de los enfrentamientos de sabios y tiranos de la tradición biográfica que hemos reseñado aquí.

Parece bastante claro que el aprovechamiento del tópico de la persecución por parte de los poderosos quedó restringido a los ámbitos cristianos, y desapareció, en cambio, de las biografías paganas. Incluso, una vez acabada la época primera de persecuciones, cuando la vida anacorética y monástica vino a reemplazar los martirios por una fuerte ascesis entendida como muerte continuada en vida a los placeres del mundo, el tópico de la resistencia a la tortura de los tiranos, hasta entonces propio de las actas martiriales, pasa también a formar parte de las renuncias de los anacoretas, aunque con formas nuevas ${ }^{40}$. Sirva como muestra este elocuente texto de Jerónimo, con automutilación de la lengua incluida (Vita Pauli 374):

${ }^{38}$ Eunapio se data habitualmente entre 347-349 y 414: cf. Goulet 1980, pp. 60-64; Blockley 1981-1983, p. I, ix, 1; Banchich 1987; Penella 1990, pp. 2-4, y, especialmente, la larga y más reciente discusión de los diversos testimonios en Goulet 2014, vol. 1, pp. 5-34.

39 Véase Goulet 2014, vol. 1, pp. 377-393.

${ }_{40}$ Para la relación de estas figuras paganas con la imagen del monje cristiano, véase Acerbi 2015. 
Alium iuuenali aetate florentem in amoenissimos hortulos praecepit adduci ibique inter candentia lilia et rubentes rosas, cum leni iuxta murmure serperet riuus et molli sibilo arborum folia uentus stringeret, super structum plumis lectulum supinari, et ne se inde posset excutere, blandis sertorum nexibus inretitum relinqui. Quo cum recedentibus cunctis meretrix speciosa uenisset, coepit delicatis stringere colla complexibus et, quod dictu quoque scelus est, manibus adtrectare uirilia, ut corpore in libidinem concitato se uictrix impudica superiaceret. Quid ageret miles Christi, quo se uerteret? Quem tormenta non uicerant superabat uoluptas. Tandem coelitus inspiratus praecisam mordicus linguam in osculantis se faciem exspuit. Ac sic libidinis sensum succedens doloris magnitudo calcauit.

A otro, en la flor de la juventud, se mandó llevarlo a unos amenísimos jardincitos. Allí, entre cándidos lirios y rosas rojas, serpeando cerca un arroyo con suave murmullo de sus aguas y meneando las hojas de los árboles el viento con blando silbido, se le tiende boca arriba sobre un lecho relleno de plumas y, para que no pudiera saltar de allí, se le deja enredado en suaves ligaduras de guirnaldas. Adonde, después de haberse retirado todos, habiendo venido una hermosa meretriz, comenzó a estrecharle el cuello con voluptuosos abrazos y, lo que también es un pecado decirlo, a palparle con las manos las partes viriles para, en el cuerpo incitado a la lascivia, tenderse encima la desvergonzada vencedora. El soldado cristiano no sabía qué hacer ni adónde volverse: al que no habían vencido los tormentos, lo comenzaba a superar la voluptuosidad. Pero al fin, por inspiración celestial, le escupió a la cara de la que lo besaba su propia lengua arrancada de un mordisco, y así a la sensación libidinosa la superó la intensidad del dolor. [Trad. V. Bejarano]

Y el caso es que el tópico le hubiera venido de perlas al bueno de Eunapio para contrarrestar una de las armas propagandísticas más importantes del cristianismo: la inmortalización tras una muerte violenta. En las biografías laercianas, en efecto, es habitual que quienes han muerto a manos de los tiranos experimenten una apoteosis celeste glorificadora, como le ocurre a Anaxarco (D. L. IX 59):

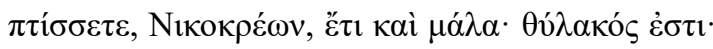

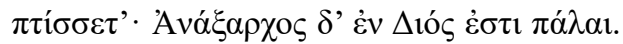

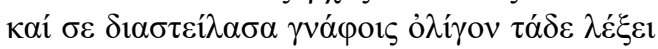

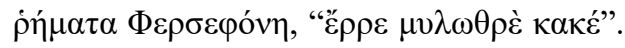

Muele, oh Nicocreonte, aún más: que es tan sólo un saco; muele: Anaxarco ya mucho ha que está junto a Zeus. 
Perséfone pronto vendrá con peines de hierro a cardarte, diciendo: «Mal haya de ti, vil y ruin moledor». [Trad. L.-A. Bredlow, ligeramente modificada]

Y también a Zenón de Elea (D. L. IX 28):

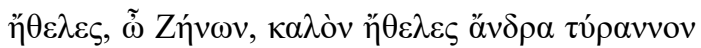

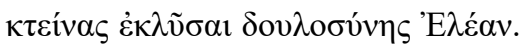

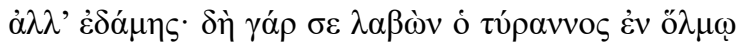

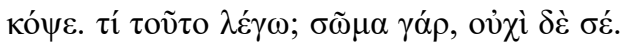

Quisiste, Zenón, y fue noble el intento, al señor y tirano dándole muerte, librar de servidumbre a Elea.

Mas sucumbiste: al prenderte el tirano, moler en mortero te hizo. ¿Qué digo yo? Sólo a tu cuerpo, no a ti. [Trad. L.-A. Bredlow]

Sin embargo, es importante remarcar que estas apoteosis celestes se producen únicamente en los epigramas, que, por más que toman evidentemente como referencia las fuentes del relato en prosa precedente, suelen reflejar los gustos e inquietudes de Diógenes Laercio, que sin duda corresponden a los de su época ${ }^{41}$. Y, no menos importante, las apoteosis celestes mediante el epigrama final se conceden también a veces a filósofos que no han sufrido en ningún caso una muerte violenta a manos de tiranos, como Polemón (D. L. IV 20), de manera que hay que reconocer que la apoteosis celeste no es en modo alguno exclusiva de los «mártires filosóficos», aunque sí que podemos afirmar que éste es siempre el destino final de quienes han sufrido este «martirio».

\section{Recapitulaciones, discontinuidades y alguna reflexión metodológica}

Los hombres divinos, pues, a pesar de continuar con el tópico del enfrentamiento con los poderosos, por un lado, y de la inmortalización mediante una difusa ascensión celestial, por otro, en ningún caso unen ambos elementos narrativos: a diferencia de los filósofos laercianos, que siguen, en éste como en tantos otros puntos, la tradición biográfica helenística, no tenemos cons-

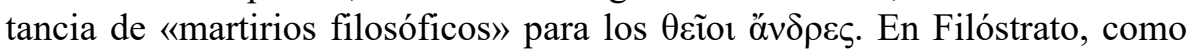

\footnotetext{
41 Véase Grau 2013.
} 
hemos visto, el enfrentamiento con Domiciano no lleva a Apolonio de Tiana a la muerte, aunque su apoteosis celestial final es bien conocida, incluidas las

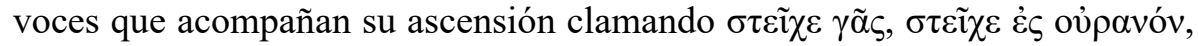
$\sigma \tau \varepsilon i \chi \chi \varepsilon$ (Philostr., VA VIII 30). En Eunapio, como hemos dicho, ni siquiera tenemos constancia de un verdadero enfrentamiento de filósofos y poderosos, al menos en los términos tradicionales.

Naturalmente, cabe preguntarse por las causas de esta distribución de tópicos en los textos tardoantiguos. Sin duda, hay una primera explicación simple en la diferencia de fuentes manejadas por cada uno de los autores: mientras que Filóstrato, Diógenes Laercio, Porfirio y Jámblico usan, habitualmente citándolas, fuentes helenísticas (sobre todo Aristóxeno, Hermipo, Hipóboto y Neantes), que son las mismas que debieron usar los autores cristianos cultos, como Jerónimo o Eusebio de Cesarea, es bien sabido que Eunapio conoce las obras de Soción, Jámblico, Porfirio y Filóstrato (VS II 1.1-3) e incluso el Demonacte de Luciano de Samósata (VS II 1.9), pero no menciona a ningún otro autor helenístico entre sus fuentes y no parece que conociera en absoluto a Diógenes Laercio, a pesar de que su obra no debía de haber desaparecido de los circuitos cultos antes del siglo $\mathrm{VI}^{42}$, y de que Sópatro de Apamea, prácticamente contemporáneo de Eunapio ${ }^{43}$, compuso todo el libro

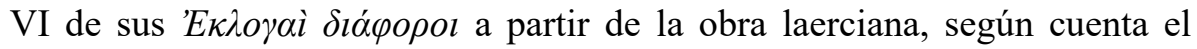
patriarca Focio (Bibl. cod. 161). En todo caso, no parece que a Eunapio le interesara demasiado ni la doxografía ni las autoridades a la hora de componer sus vidas, obnubilado por ofrecer modelos claros de una teúrgia de raigambre antigua y pagana que pudiera oponer a la cristiana: se trata, pues, sin más, de una evolución del interés por los datos disponibles.

El motivo de fondo, sin embargo, es claro: los hombres divinos del paganismo ni por asomo podían relacionarse con los mártires cristianos, porque la existencia misma de éstos escandalizaba y horrorizaba a los pensadores neoplatónicos, como se manifiesta en este conocido pasaje de Eunapio (VS VI 11.8):

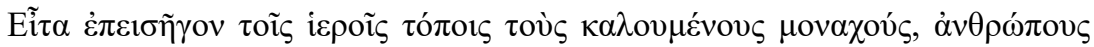

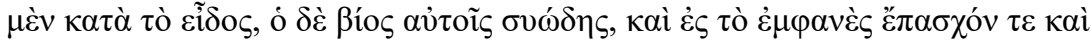

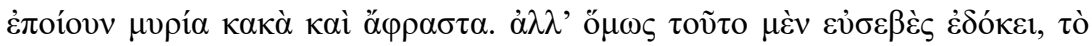

${ }^{42}$ Cuanto menos, Laercio aparece como fuente, mencionado por su nombre, de algunas

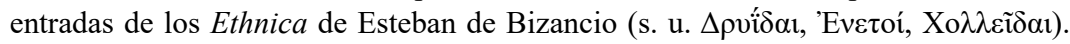

${ }^{43}$ Aunque su datación es una cuestión debatida: véase Goulet 2016. 


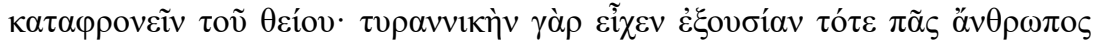

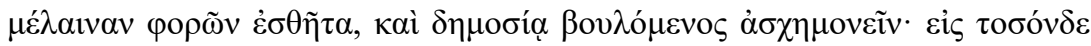

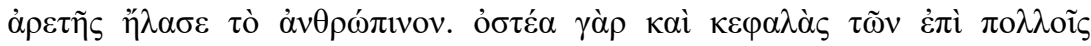

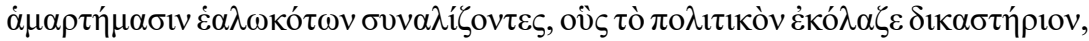

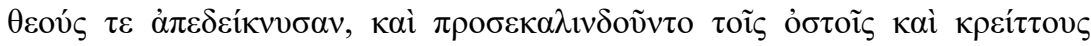

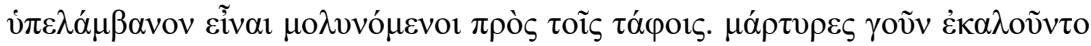

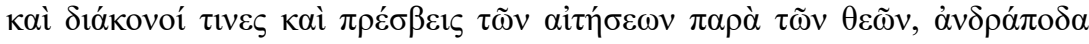

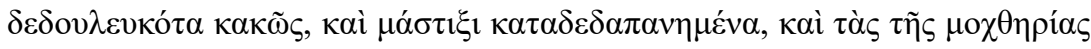

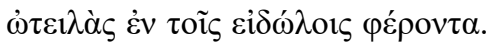

Más tarde, [los cristianos] introdujeron en los lugares sagrados a los llamados monjes, hombres de aspecto, pero de vida semejante a la de los cerdos, y que consentían y perpetraban abiertamente maldades múltiples e inefables. Pero es que, además, esto es lo que les parecía piadoso: menospreciar lo divino; un poder tiránico poseía en aquel tiempo a todo hombre que llevara vestido negro y estuviera dispuesto a comportarse en público de manera indecente: ¡a tal grado de virtud llegó la humanidad! ... Porque, recogiendo los huesos y los cráneos de quienes, imputados por numerosos crímenes, el tribunal ciudadano castigaba, los señalaron como dioses, y se revolcaban entre sus huesos y creían que serían mejores si se contaminaban ante sus tumbas. «Mártires», los llamaban, y «ministros»y «embajadores» de sus plegarias a los dioses, cuando no eran más que esclavos de mala ralea, consumidos por los latigazos y llevando en sus rostros las cicatrices de su vileza.

Los tiranos opuestos a los filósofos, pues, acaban siendo al final del camino los monjes y las autoridades que los toleran e incluso los respaldan. Se impone, por tanto, como mínimo, una reflexión metodológica final: el uso del acerbo de relatos tipificados que formaban parte de la educación retórica común a paganos y cristianos en la Antigüedad Tardía contribuye en igual medida a la definición de los nuevos paradigmas culturales, sean hombres divinos o santos, pero este uso no es en ningún caso servil ni, por supuesto, inintencionado. Fijarse atentamente en los matices de su evolución, como hemos intentado aquí, debería contribuir a esclarecer mejor las continuidades y las diferencias entre las distintas mentalidades.

\section{BIBLIOGRAFÍA}

Acerbi, S. 2015: «La parrhesia del theios aner en la historia religiosa de Teodoreto de Ciro», Estudios Clásicos 148, pp. 23-37. 


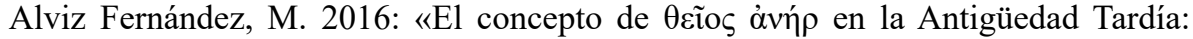
hacia un nuevo marco definitorio», Espacio, Tiempo y Forma: Revista de la Facultad de Geografia e Historia. Serie 2, Historia Antigua 29, pp. 11-25.

Anderson, G. 1994: Sage, Saint and Sophist. Holy Men and their Associates in the Early Roman Empire, Londres-Nueva York.

Banchich, T. M. 1987: «On Goulet's Chronology of Eunapius’ Life and Works», Journal of Hellenic Studies 107, pp. 164-167.

Bell, J. M. 1978: «Simonides in the Anecdotal Tradition», Quaderni Urbinati di Cultura Classica 28, pp. 29-86.

Bernard, P. 1984: «Le philosophe Anaxarque et le roi Nicocréon de Salamine», Journal des Savants 1-2, pp. 3-49.

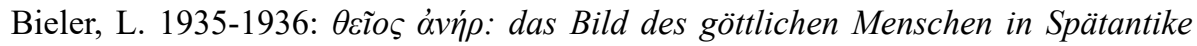
und Frühchristentum, Viena (reimpr. Darmstadt, 1976).

Blockley, R. C. 1981-1983: The Fragmentary Classicising Historians of the Later Roman Empire. Eunapius, Olympiodorus, Priscus and Malchus, 2 vols., Liverpool.

Brown, P. 1971: «The Rise and Function of the Holy Man in Late Antiquity», Journal of Roman Studies 61, pp. 81-101.

Catenacci, C. 2012: Il tiranno e l'eroe: storia e mito nella Grecia antica, Roma.

Chitwood, A. 2004: Death by Philosophy. The Biographical Tradition in the Life and Death of the Archaic Philosophers Empedocles, Heraclitus, and Democritus, Michigan.

Cortina, F. 1995: «Pítac: la caracterització del бoøóc», Ítaca 9-11, pp. 11-16.

Cox, P. 1983: Biography in Late Antiquity. A Quest for the Holy Man, Berkeley.

Detienne, M. 1967: Les maîtres de vérité dans la Grèce archaïque, París.

Dorandi, T. 1994: «De Zénon d'Élée à Anaxarque: fortune d'un topos littéraire», en Lagrée, J. y Delattre, D. (eds.), Ainsi parlaient les Anciens, Lille, pp. 27-37.

Dorandi, T. (ed.) 2013: Diogenes Laertius, Lives of Eminent philosophers, Cambridge-Nueva York.

du Toit, D. S. 1997: Theios anthropos: zur Verwendung von «theios anthrōpos» und sinnverwandten Ausdrücken in der Literatur der Kaiserzeit, Tubinga.

Fairweather, J. 1974: «Fiction in the Biographies of Ancient Writers», Ancient Society 5, pp. 231-275.

Fairweather, J. 1983: «Traditional Narratives, Influence and Truth in the Lives of the Greek Poets», Papers of the Liverpool Latin Seminar 4, pp. 315-369.

Fowden, G. 1982: «The Pagan Holy Man in Late Antique Society», Journal of Hellenic Studies 102, pp. 33-59.

Fuentes González, P. P. 2003: «¿Necesitaban de un amigo los cínicos antiguos?», Bitarte: Revista Cuatrimestral de Humanidades 31, pp. 51-72.

Geffcken, J. 1929: «Antiplatonica», Hermes 64, pp. 87-109. 
Gentili, B. 1984: Poesia e pubblico nella Grecia antica, Roma [traducción castellana: Poesía y público en la Grecia antigua, Barcelona 1996].

Giorgini, G. 1993: La città e il tiranno. Il concetto di tiranide nella Grecia del VIIIV sec. a. C., Milán.

Gómez, P. 2002: «Savis i tirans: la correspondència dels Set al llibre I de Diògenes Laerci», Ítaca 18, pp. 191-209.

Goulet, R. 1980: «Sur la chronologie de la vie et des oeuvres d'Eunape de Sardes», Journal of Hellenic Studies 100, pp. 60-72.

Goulet, R. 2014: Eunape de Sardes. Vies de philosophes et sophistes, 2 vols., París.

Goulet, R. 2016: «Sôpatros d'Apamée», en Goulet, R. (ed.), Dictionnaire des Philosophes Antiques vol. VI, pp. 459-463.

Grau, S. 2009: «Come parlavano i filosofi? Analisi delle forme espressive dei filosofi greci nella biografia antica», Lexis 27, pp. 405-446.

Grau, S. 2010: «Tipificación en la biografía griega antigua de filósofos: la construcción de una imagen preconcebida», Espíritu 140, pp. 435-492.

Grau, S. 2013: «Diogenes Laertius between Tradition and Innovation: Philosophers and $\theta \varepsilon i ̃ o 1 ~ \alpha ̋ v \delta \rho \varepsilon \varsigma »$, en García-Gasco, R., González Sánchez, S. y Hernández de la Fuente, D. (eds.), The Theodosian Age (A.D. 379-455): Power, Place, Belief and Learning at the End of the Western Empire, Oxford, pp. 183-189.

Grau, S. 2019: «Usos i abusos del vi per part dels filòsofs antics segons les biografies», en Pomer Monferrer, J. J. y Rovira, H. (eds.), Aigua $i$ vi a les literatures clàssiques i la seua recepció, Reus, pp. 63-78.

Grau, S. y Narro, A. 2013: «Vidas de filósofos y hechos apócrifos de los apóstoles: algunos contactos y elementos comunes». Estudios Clásicos 143, pp. 65-92.

Jacob, Ch. 2004: «Questions sur les questions: archéologie d'une pratique intellectuelle et d'une forme discursive», en Volgers, A. y Zamagni, C. (eds.), Erotapokriseis. Early Christian Question-and-Answer Literature in Context, LovainaParís-Dudley, pp. 25-54.

Jocelyn, H. D. 1977: «The Ruling Class of the Roman Republic and Greek Philosophers», Bulletin of the John Rylands Library 59, pp. 323-366.

Jufresa, M. y Fau, M. T. 2007: «La relación entre poeta y tirano en la Grecia arcaica», Nova Tellus 25, pp. 93-116.

Junqua, F. 2006: «Tyrans et philosophes: rôle de la correspondance dans les relations entre sagesse et pouvoir», en Laurence, P. y Guillaumont, F. (eds.) Epistulae antiquae 4. Actes du IVe colloque international L'épistolaire antique et ses prolongements européens, Lovaina, pp. 27-50.

Kivilo, M. 2010: Early Greek Poets'Lives: The Shaping of the Tradition, Leiden-Boston. Lefkowitz, M. R. 1978: «The Poet as a Hero: Fifth-Century Autobiography and Subsequent Biographical Fiction», Classical Quarterly 28, pp. 459-469.

Lefkowitz, M. R. 1981: The Lives of the Greek Poets, Baltimore. 
Lefkowitz, M. R. 2009: «Biographical Mythology», en Dill, U. y Walde, Ch. (eds.), Antike Mythen: Medien, Transformationen, und Konstruktionen (Studien in Honorem Fritz Graf), Berlín, pp. 516-531.

Lewis, S. 2006: Ancient Tyranny, Edimburgo.

Mejer, J. 1994: «Diògene Laërce», en Goulet, R. (ed.), Dictionaire des philosophes antiques, París, vol. II, pp. 824-833.

Morgan, A. K. (ed.) 2003: Popular Tyranny. Sovereignty and its Discontents in Ancient Greece, Austin.

Mossé, C. 1969: La tyrannie dans la Grèce antique, París.

Penella, R. J. 1990: Greek Philosophers and Sophists in the Fourth Century A. D. Studies in Eunapius of Sardis, Leeds.

Ricci, M. L. 1964: «Topica pagana e cristiana negli Acta Martyrum», Atti dell'Accademia Toscana «La Colombaria» 38, pp. 37-122.

Riginos, A. S. 1976: Platonica. The Anecdotes Concerning the Life and Writings of Plato, Leiden.

Ronconi, A. 1966: «Exitus illustrium uirorum», Reallexikon für Antike und Christentum VI, Stuttgart, col. 1258-1268.

Runia, D. T. 1997: «Diogenes Laertios», en Cancik, H. y Schneider, H. (eds.), Der neue Pauly III, Stuttgart, pp. 601-603.

Sánchez de la Torre, A. 1994: La tiranía en la Grecia antigua, Madrid.

Simonetti, M. 1956: "Qualche osservazione a proposito dell'origine degli Atti dei martiri», Revue d'études Augustiniennes 2, pp. 39-57.

Sollenberger, M. G. 1991-1992: «The Lives of the Peripatetics: An Analysis of the Contents and Structure of Diogenes Laertius' Vitae philosophorum Book 5», en Aufstieg und Niedergang des Römischen Welt, Band II.36.5 y II.36.6, Nueva York-Berlín, pp. 3793-3879.

Solmsen, F. 1940: «Some works of Philostratus the Elder», Transactions of the American Philological Association 71, pp. 556-572.

Stuart, D. R. 1931: «Authors' Lives as Revealed in their Works», en Classical Studies in honor of John C. Rolfe, Filadelfia, pp. 285-304.

Temmerman, K. de y Demoen, K. (eds.) 2016: Writing Biography in Greece and Rome. Narrative Technique and Fictionalization, Cambridge.

Thompson, S. 1955-19582: Motif-Index of Folk-Literature, 6 vols., Bloomington.

Yerli, Ch. 1992: «Figures du tyran archaïque: entre le monstre et le sage», en Calame, Cl. (ed.), Figures grecques de l'intermédiaire, Lausana, pp. 3-32.

Fecha de recepción de la primera versión del artículo: 17/10/2019

Fecha de aceptación: 07/02/2020

Fecha de recepción de la versión definitiva: 19/02/2020 